\title{
Investigation of Glucocorticoid Receptor Gene Bcl-1 Polymorphism in Rheumatoid Arthritis
}

\author{
Romatoid Artritte Glukokortikoid Reseptörü Geni Bcl-1 \\ Polimorfizminin Araştırılması
}

\author{
Ali AYDENIZ, ${ }^{1}$ Tuğçe SEVER, ${ }^{2}$ Sacide PEHLIVAN,${ }^{2}$ Mustafa PEHLIVAN, ${ }^{3}$ \\ Özlem ALTINDAĞ, ${ }^{1}$ Selin BÜDEYRİ, ${ }^{2}$ Savaş GÜRSOY ${ }^{1}$ \\ ${ }^{1}$ Department of Physical Medicine and Rehabilitation, Medical Faculty of Gaziantep University, Gaziantep, Turkey; \\ ${ }^{2}$ Department of Medical Biology, Medical Faculty of Gaziantep University, Gaziantep, Turkey; \\ ${ }^{3}$ Department of Hematology, Medical Faculty of Gaziantep University, Gaziantep, Turkey
}

\begin{abstract}
Objectives: In this study, we investigated the association of the human glucocorticoid receptor gene (NR3C1) Bcl-1 CG polymorphism with clinical data and response to therapy among rheumatoid arthritis (RA) patients and healthy control subjects.

Patients and methods: We performed PCR-RFLP (Polymerase chain reaction-restriction fragment length polymorphism) method for identifying restriction of the Bcl-1 fragment length polymorphisms in the intron 2 region of the NR3C1 gene in 65 patients with RA (47 females, 18 males) and 70 healthy control subjects (47 females, 23 males). Clinical parameters and demographic characteristics of the patients along with previous history of drug treatments were also recorded. In addition, patients' response to treatment was monitored with the visual analog scale (VAS), Disease Activity Scores 28 (DAS28) and Health Assessment Questionnaire (HAQ) scores.
\end{abstract}

Results: The genotype frequencies of the NR3C1 Bcl-1 polymorphism did not differ between the patients with RA and the controls. We detected a deviation from the HardyWeinberg equilibrium in the RA group for the alleles tested $(\mathrm{Rap}=0.044, \mathrm{Kp}=0.554)$. However, there was no significant difference between genotypes regarding age, gender, disease duration, or clinical parameters such as DAS28 scores, VAS and $H A Q$ values ( $p>0.05)$.

Conclusion: Although the glucocorticoid receptor gene $\mathrm{Bcl}-1$ polymorphism did not differ between the RA and control groups, we detected a deviation from the Hardy-Weinberg equilibrium in the RA group for the alleles tested. This indicates that the glucocorticoid receptor polymorphism, namely $\mathrm{Bcl}-1 \mathrm{CG}$, may play a role in the ethiopathogenesis of RA and the treatment response with glucocorticoids.

Key words: Glucocorticoid; polymorphism; rheumatoid arthritis.
Amaç: $\mathrm{Bu}$ çalışmada romatoid artritli (RA) hastalarda ve sağlıklı kontrol deneklerinde insan glukokortikoid reseptor genindeki (NR3C1) Bcl 1-CG polimorfizminin klinik veriler ve tedaviye yanıtla ilişkisi araştırıldı.

Hastalar ve yöntemler: Bu çalışmada 65 RA'lı hasta (47 kadın, 18 erkek) ve 70 sağlıklı kontrol deneğinde (47 kadın, 23 erkek) PCR-RFLP (Polimeraz zincir reaksiyonurestriksiyon parça uzunluk polimorfizmi) yöntemiyle NR3C1 geni intron 2 bölgesindeki $\mathrm{Bcl}$ I parça uzunluk polimorfizmleri çalışıldı. Hastaların önceki ilaç öyküsü ile birlikte klinik parametreleri ve demografik özellikleri de kaydedildi. Ek olarak hastalarda tedaviye yanıt görsel analog ölçeği (GAÖ), Hastalık Aktivitesi Skoru (DAS28) ve Hastalık Değerlendirme Anketi (SDA) skorlarıyla izlendi.

Bulgular: NR3C1 Bcl I polimorfizmi genotip frekansları RA'lı hastalarla kontroller arasında farklılık göstermedi. Romatoid artrit grubunda test edilen alellerde HardyWeinberg eşitliğinden bir sapma olduğu tespit edildi $(\mathrm{Rap}=0.044, \mathrm{Kp}=0.554)$. Bununla birlikte genotipler arasında yaş, cinsiyet, hastalık süresi ve GAÖ, DAS28 ve SDA gibi klinik parametreler açısından fark saptanmadı (p>0.05).

Sonuç: Glukokortikoid reseptörü geni $\mathrm{Bcl}$ I polimorfizmi RA ve kontrol grubu arasında farklılık göstermese de RA grubunda test edilen alellerde Hardy-Weinberg eşitliğinden bir sapma tespit edildi. Bu durum glukokortikoid reseptörü geni polimorfizmi Bcl I-CG'nin RA etyopatogenezinde ve glukokortikoidlerle uygulanan tedaviye gelişen yanıtta rol oynayabileceğini göstermektedir.

Anahtar sözcükler: Glukokortikoid; polimorfizm; romatoid artrit. 
Rheumatoid arthritis (RA) is a chronic inflammatory disease of unknown etiology characterized by chronic synovitis which often results in joint destruction. ${ }^{[1]}$ Glucocorticoids are used to treat a wide variety of inflammatory diseases, including RA, auto-immune diseases, allergies, and asthma. ${ }^{[2,3]}$ Glucocorticoids bind the glucocorticoid receptor (GR), also denoted as NR3C1, in the cytosol. They activate the cytosolic GR which translocates to the nucleus to regulate the target gene transcription and determine the reduction of synthesis and release of proinflammatory cytokines. ${ }^{[4,5]}$ In clinical observations, a considerable variability among subjects is seen in their sensitivity to glucocorticoid therapy, both with regard to efficacy and to the prevalance and severity of side effects.

The human GR gene is one locus on chromosome 5q31-32. An NR3C1 diallelic single nucleotide polymorphism, Bcl-1, has been reported to distinguish individuals with the highest GC sensitivity. ${ }^{[6]}$ The aim of the present study was to investigate the association between the NR3C1 gen (Bcl-1-CG) polymorphism and the response to therapy among RA patients and healthy control subjects.

\section{PATIENTS AND METHODS}

Sixty-five patients with RA and 70 unrelated healthy controls were enrolled into this study. The patients with RA were divided into two groups as anti-TNF-alpha and DMARD groups. Thirty-five patients received anti-TNF-alpha therapy (either etanercept $25 \mathrm{mg}$ subcutaneous twice weekly or infliximab $3 \mathrm{mg} / \mathrm{kg}$ infusion at weeks $0,2,6$, and then every 8 weeks and 30 patients received disease-modifying antirheumatic drugs (DMARDs). Corticosteroids and non-steroidal anti inflammatory drugs (NSAIDs) are allowed as adjuvants at the treatment period. The study was approved by the local ethics committee, and informed consent was obtained from all patients. Rheumatoid arthritis patients were diagnosed according to the American College of Rheumatology (ACR) criteria. Disease activity was determined on the basis of defined parameters. The number of tender and swollen joints (28-joint count), duration of morning stiffness (in minutes), global health and disease activity on a 0-100 $\mathrm{mm}$ visual analog scale (VAS) and the Disease Activity Score 28-joint assessment (DAS28) were calculated. Functional assessment was carried out using the Health Assessment Questionnaire (HAQ) at baseline and after six months of therapy. ${ }^{[7]}$
The distribution of the NR3C1 Bcl-1 polymorphism in the intron 2 polymorphism were evaluated in RA patients and healthy control populations by using the polymerase chain reaction-restriction fragment length polymorphism (PCR-RFLP) method. Blood samples were obtained from all subjects. Genomic DNA was extracted from mononuclear cells obtained from ethylenediaminetetraacetic acid (EDTA)treated peripheral venous blood using the salting-out method. ${ }^{[7]}$ The Bcl-1 polymorphism in the intron 2 of $\mathrm{NR} 3 \mathrm{C} 1$ was amplified using the following primer pair: Bcl1F-5'-TGCTGCCTTATTTGTAAATTCGT-3' and Bcl1R-5'-AAGCTTAACAATTTTGGCCATC-3'. DNA was amplified by a single PCR program consisting of one cycle of $95{ }^{\circ} \mathrm{C}$ for seven min, 40 cycles of $94^{\circ} \mathrm{C}$ for one min, one cycle of $56^{\circ} \mathrm{C}$ for one min, one cycle of $72{ }^{\circ} \mathrm{C}$ for $1 \mathrm{~min}$, and one cycle of $72{ }^{\circ} \mathrm{C}$ for seven min. The genotyping was determined by PCR-RFLP (Figure 1). ${ }^{[8,9]}$

\section{Statistical analysis}

The data analyses were performed using the computer software SPSS for Windows version 13.0 (SPSS Inc., Chicago, Illinois, USA). The statistical significance of the differences between the patient and control groups was estimated by logistic regression analysis. Adjusted odds ratios (ORs) were calculated with a logistic regression model that controlled for gender and age and was reported at 95\% confidence intervals (CI). Differences in Bcl-2 allele frequencies between the control group and patients were compared with a chi-square test and, when needed, Fisher's exact test was used. The Hardy-Weinberg equation was used to calculate the estimated genotype frequency and experienced genotype frequency. For statistical comparison of groups, the Mann-Whitney U-test was used. A p-value of less than 0.05 was considered statistically significant.

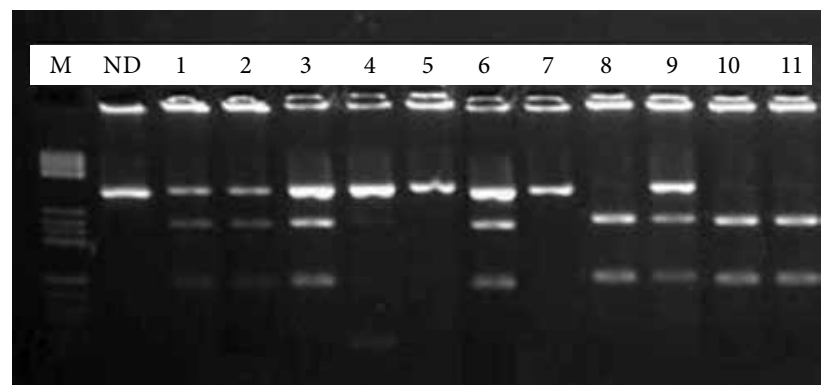

Figure 1. Agarose gel electrophoresis of NR3C1-Bcl1 fragments stained with ethidium bromide. M: DNA size standard, ND: Non-digest PCR product. The results regarding patients with RA; 1-4,6,9: GC/8,10,11: CC/5,7: GG. 


\begin{tabular}{|c|c|c|c|c|c|c|c|c|c|c|c|c|c|c|c|}
\hline & \multicolumn{6}{|c|}{ Anti TNF-alpha treatment } & \multicolumn{6}{|c|}{ DMARD treatment } & \multicolumn{2}{|c|}{ Control } & \multirow[b]{2}{*}{$p$} \\
\hline & $\mathrm{n}$ & $\%$ & Range & Mean \pm SD & Med. & (min.-max.) & $\mathrm{n}$ & $\%$ & Range & Mean \pm SD & Med. & (min.-max.) & $\mathrm{n}$ & Range & \\
\hline No. of patients & 35 & & & & & & 30 & & & & & 70 & & & \\
\hline Age & 50 & & $38-65$ & & & & 47 & & $29-78$ & & & & 50 & $29-76$ & NS \\
\hline \multicolumn{16}{|l|}{ Gender } \\
\hline Male & 8 & & & & & & 10 & & & & & & 23 & & NS \\
\hline Female & 27 & & & & & & 20 & & & & & & 47 & & NS \\
\hline Disease duration & & & & $9.5 \pm 10.4$ & 8.2 & $(0.6-15.5)$ & & & & $8.7 \pm 7.5$ & 7.8 & $(0.6-13.8)$ & & & NS \\
\hline $\mathrm{RF}+$ & 41 & 82 & & & & & 37 & 79 & & & & & & & NS \\
\hline \multicolumn{16}{|l|}{ DAS28 scores } \\
\hline Week 0 & & & & $4.9 \pm 1.6$ & 4.63 & $(2.33-7.89)$ & & & & $5.3 \pm 1.1$ & 5.17 & $(3.4-7.32)$ & & & NS \\
\hline Week 24 & & & & $3.4 \pm 1.3$ & 3.20 & $(1.36-5.94)$ & & & & $4.3 \pm 1.1$ & 4.14 & $(1.87-6.79)$ & & & 0.004 \\
\hline \multicolumn{16}{|l|}{$\begin{array}{l}\text { Improvement } \\
\text { in DAS28 scores }\end{array}$} \\
\hline Week 0/24 & & & & $1.5 \pm 1.0$ & 1.49 & $(-0.17-3.67)$ & & & & $1.0 \pm 1.0$ & 0.82 & $(-0.9-3.3)$ & & & $0.051 \mathrm{NS}$ \\
\hline \multicolumn{16}{|l|}{ VAS } \\
\hline Week 0 & & & & $39.4 \pm 20.0$ & 55 & $(20-90)$ & & & & $45.7 \pm 17.2$ & 70 & $(20-90)$ & & & NS \\
\hline Week 24 & & & & $24.6 \pm 15.7$ & 40 & $(10-80)$ & & & & $44.8 \pm 15.3$ & 62 & $(30-85)$ & & & $<0.001$ \\
\hline \multicolumn{16}{|l|}{ HAQ } \\
\hline Week 0 & & & & $0.9 \pm 0.8$ & 0.87 & $(0-2.25)$ & & & & $0.7 \pm 0.6$ & 0.56 & $(0-2)$ & & & NS \\
\hline Week 24 & & & & $0.7 \pm 0.6$ & 0.5 & $(0-2)$ & & & & $0.7 \pm 0.6$ & 0.5 & $(0.2)$ & & & NS \\
\hline
\end{tabular}

\section{RESULTS}

The demographic characteristics of the patients and their responses to treatment after 24 weeks of therapy are shown in table 1 . The mean age of the patients in the anti-TNF-alpha, DMARD, and control groups did not differ significantly [50 (38-65) in anti-TNF-alpha the etanercept group, 47 (29-78) in the DMARD group and 50 (29-76) in the control group]. Mean disease durations were similar in the anti-TNF group $(9.5 \pm 10.4$ years) and in the DMARD group $(7.5 \pm 8.7$ years). The mean VAS and HAQ score were not significant in either group. At six months, the mean DAS28 improvement was not significant among the groups $(\mathrm{p}=0.051)$.

Digestion of PCR product by the Bcl-1 enzyme generated one fragment for homozygous $G / G$, three fragments for heterozygote $\mathrm{G} / \mathrm{C}$, and two fragments for homozygous $\mathrm{C} / \mathrm{C}$ (Figure 1).
Genotype frequencies of the NR3C1 Bcl-1 polymorphism did not differ between the patients with RA and the controls (table 2). We detected a deviation from the Hardy-Weinberg equilibrium in the RA group for the alleles tested $(\mathrm{Rap}=0.044, \mathrm{Kp}=0.554)$.

When we considered the correlation between allelic distribution of the NR3C1 Bcl-1 polymorphism and clinical parameters such as the DAS28 scores, VAS, and HAQ values, we didn't find also any statistical significance among the groups (table 3).

\section{DISCUSSION}

Although glucocorticoids are successfully used in the treatment of a wide range of rheumatic and other inflammatory diseases, few patients with these diseases show a poor response or absence of response to even high doses of glucocorticoids. ${ }^{[8-10]}$ The molecular basis of generalized glucocorticoid resistance has been ascribed

Table 2. Frequency of Bcl-1 genotypes in control and rheumatoid arthritis cases

\begin{tabular}{|c|c|c|c|c|c|c|c|}
\hline \multirow[t]{2}{*}{ NR3C1 gene } & \multicolumn{2}{|c|}{ Rheumatoid arthritis $(n=65)$} & \multicolumn{2}{|c|}{ Healthy control $(n=70)$} & \multirow[t]{2}{*}{ OR } & \multirow[t]{2}{*}{$95 \% \mathrm{CI}$} & \multirow[t]{2}{*}{$p$} \\
\hline & $\mathrm{n}$ & $\%$ & $\mathrm{n}$ & $\%$ & & & \\
\hline \multicolumn{8}{|c|}{ BCL-1 polymorphism } \\
\hline \multicolumn{8}{|c|}{ Genotype } \\
\hline $\mathrm{CC}$ & 35 & 53.8 & 42 & 60 & $3.023^{*}$ & $0.870-10.506^{\star}$ & $0.082^{*}$ \\
\hline CG & 20 & 30.8 & 24 & 34.3 & $2.933^{*}$ & $0.795-10.821^{\star}$ & $0.106^{*}$ \\
\hline GG & 10 & 15.4 & 4 & 5.7 & $3.000 \dagger$ & $0.891-10.096 \dagger$ & $0.090 \dagger$ \\
\hline
\end{tabular}


Table 3. Bcl-1 genotypes of rheumatoid arthritis patients in association with clinical parameters

\begin{tabular}{|c|c|c|c|c|c|c|c|c|c|c|c|c|}
\hline & \multicolumn{4}{|c|}{ DAS28 scores ${ }^{*}$} & \multicolumn{4}{|c|}{ VAS $^{*}$} & \multicolumn{4}{|c|}{$\mathrm{HAQ}^{*}$} \\
\hline & Mean \pm SD & Med. & (min.-max.) & $p \dagger$ & Mean \pm SD & Med. & (min.-max.) & $p^{\dagger}$ & Mean \pm SD & Med & $\min .-\max )$. & $p^{\dagger}$ \\
\hline \multicolumn{13}{|l|}{ BCL-1 } \\
\hline $\mathrm{CC}^{\mathrm{a}}(\mathrm{n}=35)$ & $4.9 \pm 1.4$ & 4.85 & $(2.48-7.9)$ & $0.627^{\mathrm{ac}}$ & $55.0 \pm 15.9$ & 65 & $(20-80)$ & $0.510^{a c}$ & $0.9 \pm 0.7$ & 0.87 & $(0-2.25)$ & $0.226^{a c}$ \\
\hline $\mathrm{CG}^{\mathrm{b}}(\mathrm{n}=20)$ & $5.4 \pm 1.3$ & 4.87 & $(3.75-7.7)$ & $0.282^{\mathrm{ab}}$ & $58.8 \pm 18.9$ & 68 & $(20-90)$ & $0.197^{\mathrm{ab}}$ & $0.8 \pm 0.8$ & 0.5 & $(0-2.2)$ & $0.400^{\mathrm{ab}}$ \\
\hline $\mathrm{GG}^{\mathrm{c}}(\mathrm{n}=10)$ & $5.1 \pm 1.5$ & 5.27 & $(2.33-7.33)$ & $0.965^{\mathrm{bc}}$ & $56.7 \pm 28.4$ & 70 & $(20-85)$ & $0.965^{b c}$ & $0.6 \pm 0.4$ & 0.56 & $(0-2.25)$ & $0.710^{\mathrm{bc}}$ \\
\hline
\end{tabular}

DAS28: Disease Activity Score 28. VAS: Disease activity score; HAQ: Health Assessment Questionnaire; SD: Standard deviation; Med.: Median; ${ }^{*}$ Mean-week 0 ; p $\uparrow$ Mann-Whitney U-test; ac: Statistics between CC genotype and GG genotype; ab: Statistics between CC genotype and CG genotype; bc: Statistics between CG genotype and GG genotype.

to mutations in the hGR gene, which impair one or more of the molecular mechanisms of hGR action, thereby altering tissue sensitivity to glucocorticoids. Several polymorphisms of the gene which might have an impact on glucocorticoid sensitivity have been reported. ${ }^{[1-14]}$

In this report, we didn't determine any significant differences in the NR3C1 Bcl-1 polymorphism among the RA patients or healthy controls. Also, there was no correlation between the clinical parameters of RA and the polymorphisms. The results of this analysis may be related to the fact that the patients belonged to the same area of Turkey. Most of the RA patients in our group had high disease activity which may be related to the lack of regular admittance of patients to clinics or to inappropriate drug use.

Derijk et al $^{[15]}$ reported a newly identified polymorphism in the hGR gene in exon9beta, in an "ATTTA" motif, was significantly associated with RA. In another study, however, no significant difference was obtained among 198 RA patients and the control subjects when three GR polymorphisms (intron B Bcl-1polymorphism, a ttg insertion/deletion within intron $\mathrm{F}$ (rs2307674) and the single nucleotide polymorphism (SNP) lying in the 3' untranslated region of exon 9b). ${ }^{[16]}$ Chatzikyriakidou et al, ${ }^{[17]}$ explored the association among RA susceptibility and the GR- $\alpha$ polymorphisms rs33388, rs33389, Bcl-1, and GR- $\beta$ variant rs6198 in 136 RA patients. They concluded that the GR- $\alpha$ and GR- $\beta$ polymorphism are potentially associated with RA susceptibility. In another study, the hGR +647G/C genetic polymorphism was investigated in Korean patients with RA, but no difference between the RA and control groups was reported.$^{[18]}$ Our results support most of the previous reports, but, as far as we know, this is the first study which compares the clinicial severity of RA and NR3C1 gene polymorphisms.

Another heavily-studied autoimmune disease is systemic lupus erythematosus (SLE). Lee et $\mathrm{al}^{\left[{ }^{[19]}\right.}$ showed a single mutation in exon 9 of the GR gene in $11 / 132(8.3 \%)$ of 66 patients with SLE whereas no mutations were detected in 52 healthy individuals.

The variation in time required to obtain the cessation of proteinuria in children with nephrotic syndrome represents one aspect of the variations shown by these children in response to glucocorticoid therapy. In a study which consisted of 118 children with nephrotic syndrome, the Bcl-1 polymorphism was assessed, and the GTA haplotype was found to be associated with a higher sensitivity to steroid treatment as determined by time to proteinuria resolution. ${ }^{[20]}$

The glucocorticoid receptor gene NR3C1 has been widely studied in other inflammatory and autoimmune diseases, such as cystic fibrosis, asthma, and Graves ophthalmopathy. ${ }^{[21-23]}$

In conclusion glucocorticoid resistance is important in several inflammatory diseases, including RA, and this complicates their clinical management. The glucocorticoid receptor polymosrphism Bcl1-CG may be one of the gene candidates for ethiopathogenesis and response to treatment with glucocorticoids. The authors suggest that further studies are needed to better elucidate the relationship between GR variants and RA.

\section{Declaration of conflicting interests}

The authors declared no conflicts of interest with respect to the authorship and/or publication of this article.

\section{Funding}

The authors received no financial support for the research and/or authorship of this article.

\section{REFERENCES}

1. Rhen $\mathrm{T}$, Cidlowski JA.Antiinflammatory action of glucocorticoids-new mechanisms for old drugs. N Engl J Med 2005;353:1711-23. 
2. Chikanza IC. Mechanisms of corticosteroid resistance in rheumatoid arthritis: a putative role for the corticosteroid receptor beta isoform. Ann N Y Acad Sci 2002;966:39-48.

3. Schaaf MJ, Cidlowski JA. Molecular mechanisms of glucocorticoid action and resistance. J Steroid Biochem Mol Biol 2002;83:37-48.

4. Tait AS, Butts CL, SternbergEM. The role of glucocorticoids and progestins in inflammatory, autoimmune, and infectious disease. J Leukoc Biol 2008;84:924-31.

5. Wikström AC. Glucocorticoid action and novel mechanisms of steroid resistance: role of glucocorticoid receptor-interacting proteins for glucocorticoid responsiveness. J Endocrinol 2003;178:331-7.

6. Stevens A, Ray DW, Zeggini E, John S, Richards HL, Griffiths CE, et al. Glucocorticoid sensitivity is determined by a specific glucocorticoid receptor haplotype. J Clin Endocrinol Metab 2004;89:892-7.

7. Bachmann AW, Sedgley TL, Jackson RV, Gibson JN, Young RM, Torpy DJ. Glucocorticoid receptor polymorphisms and post-traumatic stress disorder. Psychoneuroendocrinology 2005;30:297-306.

8. Jessop DS, Harbuz MS. A defect in cortisol production in rheumatoid arthritis: why are we still looking? Rheumatology (Oxford) 2005;44:1097-100.

9. Buttgereit F, Scheffold A. Rapid glucocorticoid effects on immune cells. Steroids 2002;67:529-34.

10. Barnes PJ, Adcock IM. Glucocorticoid resistance in inflammatory diseases. Lancet 2009;373:1905-17.

11. Zhou J, Cidlowski JA. The human glucocorticoid receptor: one gene, multiple proteins and diverse responses. Steroids 2005;70:407-17.

12. Kino T, Chrousos GP. Tissue-specific glucocorticoid resistance-hypersensitivity syndromes: multifactorial states of clinical importance. J Allergy Clin Immunol 2002;109:609-13.

13. Kino T, De Martino MU, Charmandari E, Mirani M, Chrousos GP. Tissue glucocorticoid resistance/ hypersensitivity syndromes. J Steroid Biochem Mol Biol 2003;85:457-67.
14. Charmandari E, Kino T, Ichijo T, Chrousos GP. Generalized glucocorticoid resistance: clinical aspects, molecular mechanisms, and implications of a rare genetic disorder. J Clin Endocrinol Metab 2008;93:1563-72.

15. Derijk RH, Schaaf MJ, Turner G, Datson NA, Vreugdenhil E, Cidlowski J, et al. A human glucocorticoid receptor gene variant that increases the stability of the glucocorticoid receptor beta-isoform mRNA is associated with rheumatoid arthritis. J Rheumatol 2001;28:2383-8.

16. Donn R, Payne D, Ray D. Glucocorticoid receptor gene polymorphisms and susceptibility to rheumatoid arthritis. Clin Endocrinol (Oxf) 2007;67:342-5.

17. Chatzikyriakidou A, Georgiou I, Voulgari PV, Georgiadis AN, Argyriou ES, Drosos AA. Glucocorticoid receptor variants may predispose to rheumatoid arthritis susceptibility. Scand J Rheumatol 2009;38:1-5.

18. Lee EB, Kim JY, Lee YJ, Song YW. Glucocorticoid receptor polymorphisms in Korean patients with rheumatoid arthritis. Ann Rheum Dis 2005;64:503-4.

19. Lee YM, Fujiwara J, Munakata Y, Ishii T, Sugawara A, Kaku M, et al. A mutation of the glucocorticoid receptor gene in patients with systemic lupus erythematosus. Tohoku J Exp Med 2004;203:69-76.

20. Zalewski G, Wasilewska A, Zoch-Zwierz W, Chyczewski L. Response to prednisone in relation to NR3C1 intron B polymorphisms in childhood nephrotic syndrome. Pediatr Nephrol 2008;23:1073-8.

21. Corvol H, Nathan N, Charlier C, Chadelat K, Le Rouzic P, Tabary $\mathrm{O}$, et al. Glucocorticoid receptor gene polymorphisms associated with progression of lung disease in young patients with cystic fibrosis. Respir Res 2007;8:88.

22. Lovén J, Svitacheva N, Jerre A, Miller-Larsson A, Korn SH. Anti-inflammatory activity of beta2-agonists in primary lung epithelial cells is independent of glucocorticoid receptor. Eur Respir J 2007;30:848-56.

23. Boyle B, Korányi K, Patocs A, Liko I, Szappanos A, Bertalan R, et al. Polymorphisms of the glucocorticoid receptor gene in Graves ophthalmopathy. Br J Ophthalmol 2008;92:131-4. 